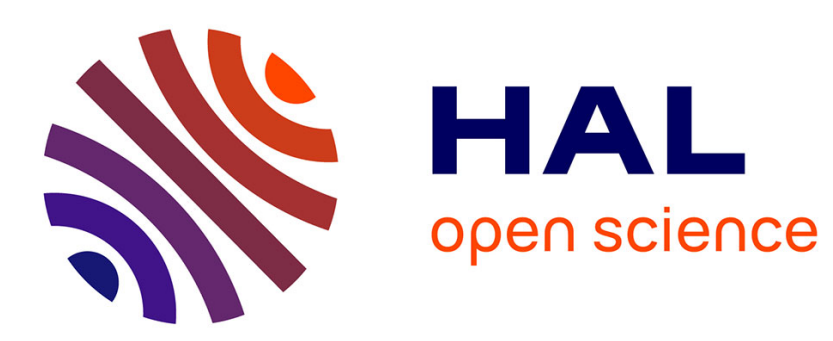

\title{
Review symposium: The theory and practice of multicultural theorizing
}

Christine Chwaszcza

\section{To cite this version:}

Christine Chwaszcza. Review symposium: The theory and practice of multicultural theorizing. Ethnicities, 2008, 8 (2), pp.261-265. 10.1177/14687968080080020103 . hal-00571896

\section{HAL Id: hal-00571896 \\ https://hal.science/hal-00571896}

Submitted on 1 Mar 2011

HAL is a multi-disciplinary open access archive for the deposit and dissemination of scientific research documents, whether they are published or not. The documents may come from teaching and research institutions in France or abroad, or from public or private research centers.
L'archive ouverte pluridisciplinaire HAL, est destinée au dépôt et à la diffusion de documents scientifiques de niveau recherche, publiés ou non, émanant des établissements d'enseignement et de recherche français ou étrangers, des laboratoires publics ou privés. 


\section{The theory and practice of multicultural theorizing}

\section{CHRISTINE CHWASZCZA}

European University Institute, Italy

Multicultural Odysseys reports a success story - the successful promotion of the doctrine of liberal multiculturalism in the academic networks and legal-bureaucratic circles of international organizations (p. 247f.). As Will Kymlicka concedes with a degree of academic honesty often lacking today, in international practice the doctrine has been less successful, if not a failure (p. 248f.). The foreword promises to investigate the causes responsible for the gap between theory and practice. According to Kymlicka, those causes are to be found primarily in practice and on the level of implementation. I disagree.

Focusing on Chapter 7 - 'The Global Challenge' - I would like to highlight two purely theoretical problems in the attempt to export the doctrine of liberal multiculturalism as a model of conflict resolution from Canada to 'postcolonial' states. Kymlicka's diagnosis, that the main obstacles to success have been political resistance to reform and inappropriate preconditions, sets up a scapegoat that distracts attention from theoretical and methodological limits of the doctrine itself that would have prohibited any attempt to export it to begin with. The first criticism concerns the theoretical structure behind the ideal of liberal multiculturalism, the second Kymlicka's image of the structure of international law and the problem that he calls 'sequencing' (p. 254), i.e. the relation between individual human rights and cultural group rights. On the basis of the two criticisms, my conclusion addresses Kymlicka's question as to whether normative approaches towards conflict resolution in international law and international politics should adopt the strategy of articulating 'general' or rather 'targeted' norms.

Like most liberal theories of justice - especially those inspired by Rawls's Theory of Justice (1971) - the doctrine of liberal multiculturalism is a theory of just institutions. Despite his disagreement concerning the normative significance of group-affiliations, Kymlicka endorses Rawls's general approach, which develops the ideal of a well-ordered institutional democracy. The complex social practices that constitute the institutional framework of the normative approach are an integral part of the concept of justice that it develops. It should be evident from the very beginning that normative requirements and ideals cannot be simply transferred to whatever conditions and conflicts prevail in practice, but must be adjusted to the empirical-practical conditions they are supposed to address. 
Normative theorizing therefore can never be an exercise of pure normative arguments detached from the structure and conflicts that characterize empirical practice and the conditions of its normative reform or improvement. That makes normative theorizing inevitably 'contextual', at least if it is supposed to be of any practical relevance at all. As a consequence, one cannot simply 'apply' a normative theoretical idea to different empirical contexts, but has to develop different approaches in order to be able to address the specific practical conflicts and the particular sociopolitical environment that are one's concern.

Notwithstanding a common tendency to indulge in 'ideal' theory and to recast the analysis of sociopolitical practice exclusively as a task of 'justifying' normative goals and moral ideals, normative theorizing cannot avoid facing and analyzing the specific sociopolitical and institutional reality that is addressed. It therefore should not come as a surprise that normative theories can neither simply be applied to different sociopolitical realities nor exported from one problem area to another.

Since the structural differences between the type of conflict that Kymlicka hopes to address and the cultural conflicts in 'postcolonial' countries are partly acknowledged by Kymlicka, and elaborated by Andreas Wimmer, I will not repeat the need to recognize those differences. But I would like to stress that the failure to export liberal multiculturalism reflects not a problem of 'empirical preconditions,' but bad methodology and a mistaken image of the structure of normative theory.

The first criticism can be deepened. Personally, I have to confess that it has always escaped me why membership in a particular culture ought to be accepted as having the deep normative significance that Kymlicka and other multiculturalists assign to it. To be sure, it cannot be doubted that human beings cannot flourish outside some cultural environment. But the normative significance of being a member of a particular and specific culture or nation that is different from others (or more precisely different from the majority culture) is far from clear to me - especially if all cultures ought to be considered to be equally inherently valuable for their members.

My suspicion has always been that the driving force behind liberal multiculturalism is an egalitarian conception of (social) justice, and that multiculturalist politics are favored as a means - or path - to promote more social equality. The hidden rationale behind the enterprise obviously must be the conviction that social inequality runs parallel to group-membership and is caused by an unequal 'distribution of sociopolitical advantages' among groups. Multicultural Odysseys confirms that suspicion.

Regardless of the plausibility of the hidden rationale, the difficulties of identifying 'minority cultures' in conflicts that do not exhibit the 'majoritysuppresses-minority-pattern', and the problems that arise when the current cultural (national) minority has itself been suppressive or acted unjustly in the (postcolonial) past, illustrate not only conceptual difficulties, but a 
normative lacuna of liberal multiculturalism. Is it really justified or even obligatory to respect the normative significance of cultural affiliations if it nourishes conflict? Ought liberals to respect and protect 'minority cultures' if they are suppressive? And if the answer to the previous questions is 'no', that is to say, if the crucial concerns of justice are about peace, social justice and standards of egalitarian citizenship, what is then the normative significance of group affiliations and why should liberal multiculturalism be internationally promoted? Sadly, those questions remain unaddressed in Multicultural Odysseys.

The only place where Kymlicka comes close to addressing the limits of the doctrine of liberal multiculturalism occurs in his discussion of 'sequencing'. Here, Kymlicka considers the practical need to increase respect for individual human rights before implementing liberal multiculturalism in order to establish the sociopolitical preconditions that are necessary for multiculturalist politics to work. Where group-membership can become a matter 'of life and death', as Kymlicka observes, a step-by-step-approach starting from the protection of individual rights, moving towards differential treatment of cultural groups, might be advisable.

As a liberal, one might ask whether there really is a problem of sequencing. At least within the liberal paradigm it seems obvious that the protection of individual rights to life and subsistence ought to be given priority above differential treatment - not temporal, but normative priority - if the two conflict in such dramatic ways. The reason is not only that the protection of individual life and liberty weighs heavier than the value of cultural affiliations, but also that the protection of individuals' human rights overrides concerns of inter-group justice.

Now, Kymlicka seems to think that the two kinds of normative concerns have an equal status, at least in the framework of contemporary international law. Such a view is suggested by his claim that the renaissance of the purpose of minority protection in the period after 1989 resembles or revives legal concerns of international law that predated the Second World War. That claim, I think, reflects a serious misunderstanding of the normative context that has been established by the development of humanitarian law and the international human rights regimes in the second half of the 20th century. It decontextualizes the minority-rights concern in international law and international relations. Even if contemporary documents use a similar terminology to earlier ones, the meaning and the intention behind those documents must be interpreted against the legal, normative and institutional context that has developed in the post-Second World War period.

To the extent that international law has come to be conceived of as a (modest) constraint for the legitimacy of domestic legal and political orders, this 'new' form of interventionism cannot be detached from the overall structure and purposes of post-war international law. Martha Finnemore 
(cf. Finnemore, 2003), among others, has highlighted the structural differences between pre-Second World War minority protection and interventionism on the one hand, and contemporary practice on the other. Whereas the former was to a significant extent Euro-chauvinistic, partisan Christian, and conducted for national interest, the 'new interventionism' is driven by human rights concerns about the victims and an ideal of collective security that opposes the promotion of 'national' interest - or other forms of group interests - but receives its normative justification from the legal (and moral) principles of international human rights law.

Historically and systematically, the recent initiatives for minority rights in international law are better understood as a development of human rights concerns, whereby the focus on group rights expresses not so much a commitment to normative support of cultural groups per se, but a response to the particular structure of the kinds of conflicts that are addressed. In other words, it more likely reflects a pragmatic rather than a normative attitude.

That leaves us with the question of how to proceed, be it within or beyond liberal multiculturalism. Kymlicka's question of whether international norms in support of domestic justice should be general or targeted remains untouched.

Although I have myself argued for 'new interventionism' (cf. Chwaszcza, 2007), I share a general skepticism towards attempts to develop general normative solutions for cultural and sociopolitical conflicts in postcolonial states. The empirical evidence we have from peace-keeping, peaceenforcement, post-conflict reconstruction and humanitarian intervention so far do not support the search for general theories and grand design. Even worse, recent studies by Roland Paris or Michael Ignatieff, and others, indicate that liberal ideals of justice have proven unapt as a method for conflict resolution in divided societies (cf. Paris, 2004; Ignatieff, 2003).

Given the fact that internal (violent or pre-violent) conflicts almost always result from a syndrome of causes and are maintained for a multiplicity of reasons, a theoretically modest case-oriented approach seems more reasonable. It therefore seems advisable to postpone the search for 'norms' - be they general or targeted - and to rely instead on normatively informed judgments for case to case. Our normative ideals provide no practically informative guidance, as long as we do not understand the empiricalpractical sides of particular cultural and sociopolitical conflicts.

The problem is far from new or unique. Those, for example, who still believe that there exists such a thing as 'development economics' and not just neo-classical economics, have basically given up the idea of developing a general theory, because the causes and situational factors that hinder development are so heterogeneous that it does not make sense to look for a general theory or for general recipes.

The practical failure of the doctrine of liberal multiculturalism in this 
sense is not exceptional. But given the rise of intra-state cases of violent conflicts in recent decades, now is neither the time for academic networking, nor for the application of ideal theory, but for interdisciplinary cooperation and the courage to reassess traditional premises of political liberalism. By trying to reassess the practical success of liberal multiculturalism, Multicultural Odysseys is making a step in such a direction.

\section{References}

Chwaszcza, Christine (2007) Moral Responsibility and Global Justice: A Human Rights Approach. Baden-Baden: Nomos.

Finnemore, Martha (2003) The Purpose of Intervention. Ithaca, NY/London: Cornell University Press.

Ignatieff, Michael (2003) 'State Failure and Nation-building', in J.L. Holzgrefe and

Robert O. Keohane (eds) Humanitarian Intervention, pp. 299-321. Cambridge:

Cambridge University Press.

Paris, Roland (2004) At War's End: Building Peace after Civil Conflict. Cambridge: CUP.

Rawls, John (1971) A Theory of Justice. Cambridge, MA: Harvard University Press.

CHRISTINE CHWASZCZA is Professor of social and political theory in the Department of Political and Social Sciences, at the European University Institute. Address: European University Institute, Via dei Roccettini 9, I-50014 San Domenico di Fiesole (FI), Italy. [email: Christine.Chwaszcza@eui.eu]

\section{Kymlicka's odyssey - lured by norms into the rocks of politics}

\section{GWENDOLYN SASSE}

University of Oxford, UK

Will Kymlicka has written another major study of multiculturalism that will keep the academic community occupied for years to come and attract the attention of policy makers. The title of his new book - Multicultural Odysseys - evokes the image of long and nightmarish journeys, though there is no apparent Odysseus-type protagonist in the story he tells. The book is written in the style of an extended essay and places Kymlicka's 